\title{
Cellophane, the New Visuality, and the Creation of Self-Service Food Retailing
}

Ai Hisano

Working Paper 17-106 


\section{Cellophane, the New Visuality, and the Creation of Self-Service Food Retailing}

\section{Ai Hisano}

Harvard Business School

Working Paper 17-106 
Cellophane, the New Visuality, and the Creation of Self-Service Food Retailing

Ai Hisano

\begin{abstract}
$\underline{\text { Abstract }}$
This working paper examines how innovations in transparent packaging, specifically cellophane, in the mid-twentieth century United States helped retailers to create full self-service merchandising systems, including selling perishable food. While self-service stores began appearing in the late 1910 s, self-service was initially applied only to grocery and dry goods, such as canned foods and a box of breakfast cereals. It was not until after World War II that the majority of American grocers adopted self-service to meat and produce sections. Business historians have explored the development of this self-service merchandising from the perspectives of marketing strategies, store operations, and relationships between customers and store clerks. However, the significance of the development of cellophane as a new packaging material, and the role of packaging manufacturers in promoting self-service, has yet to be analyzed. This working paper fills this void by showing that the expansion of self-service operation and the increasing use of transparent packaging had a significant impact not only on how consumers purchased foods but also on how they understood food quality.
\end{abstract}


Cellophane, the New Visuality, and the Creation of Self-Service Food Retailing

Ai Hisano

\section{Introduction}

This working paper examines how innovations in transparent film became a major factor that helped expand and popularize self-service food retailing. It focuses on the American food industry roughly from the 1920 s to the 1950 s, a time when self-service merchandising emerged as the dominant way of selling perishable items. The United States pioneered the development of a modern self-service retailing system. ${ }^{1}$ It was also the largest food market at the time.

Cellophane was the earliest clear packaging film. In the mid-1920s to the 1950s, it became an increasingly important packaging material in the sale of many products, including food. The film was particularly well suited to self-service retailing. It served as an effective merchandising aid for many retailers, as it helped consumers make buying decisions for themselves based on sight, while keeping food products fresh and clean.

By analyzing the development of cellophane and marketing rhetoric for selling transparent packaging, this working paper seeks to expand the historical understanding of selfservice food retailing. Historians have explored how the emergence of new food packaging, such as cartons and cans, changed food retailing and purchasing substantially in the late nineteenth and early twentieth centuries. ${ }^{2}$ They have also examined extensively the transformation of food distribution and retailing systems and the rise of self-service stores by analyzing the development

\footnotetext{
${ }^{1}$ Andrew Alexander, Gareth Shaw, and Louise Curth, "Promoting Retail Innovation: Knowledge Flows During the Emergence of Self-Service and Supermarket Retiling in Britain," Environment and Planting A 37 (5) (2005): $805-$ 821.

${ }^{2}$ Susan Strasser, Satisfaction Guaranteed: The Making of the American Mass Market (New York: Pantheon Books, 1989).
} 
of marketing strategies, the transformation of architectural structures and grocery operation, the shifting relationships between customers and store clerks, and consumer reactions to the introduction of self-service merchandising. ${ }^{3}$

This study adds to the existing historical literature on self-service retailing by showing that the transformation of food packaging was a crucial factor in establishing a self-service system. In his historical study of the meat-packing industry, Roger Horowitz identified the introduction of cellophane as a key driver in developing the self-service retailing of fresh meat. By analyzing the production and marketing of the transparent film, Horowitz also discussed the role of E. I. du Pont de Nemours \& Company (hereafter DuPont) - the primary manufacturer of cellophane in the United States - in promoting self-service meats. ${ }^{4}$ While advertising the use of cellophane, DuPont stressed the advantage of self-service merchandising, including the ease of handling products, better visibility, and quicker service. This working paper builds on Horowitz's argument that cellophane and its manufacturer, DuPont, played a critical role in expanding and popularizing self-service operation in grocery businesses. Yet the paper broadens his focus on meat products and provides broader consequences of the increasing use of transparent packaging and the expansion of self-service operation. By examining the importance of cellophane as a "scientific" and "modern" material in a particular historical and cultural

\footnotetext{
${ }^{3}$ Andrew Alexander, Simon Phillips, and Gareth Shaw, "Retail Innovation and Shopping Practices: Consumers' Reactions to Self-Service Retailing Environment and Planning A 40 (9) (2008): 2204-2221; Adrian R. Bailey, Gareth Shaw, Andrew Alexander, and Dawn Nell, "Consumer Behaviour and the Life-Course: Shopper Reactions to Self Service Grocery Shops and Supermarkets in England c.1947-1975," Environment and Planning A 42 (6) (2010): 1496-1512; Tracey Deutsch, Building a Housewife's Paradise: Gender, Politics, and American Grocery Stores in the Twentieth Century (Chapel Hill: University of North Carolina Press, 2010); Peter Lummel, "Born-inthe-City: The Supermarket in Germany," in Food and the City in Europe since 1800, eds. Peter J. Atkins, Peter Lummel, and Derek J. Oddy (New York: Routledge, 2007): 165-76; James M. Mayo, The American Grocery Store: The Business Evolution of an Architectural Space (Westport, CT: Greenwood Press, 1993); and Richard S. Tedlow, New and Improved: The Story of Mass Marketing in America (Boston: Basic Books, 1996); Leigh Sparks, "The Rise and Fall of Mass Marketing?: Food Retailing in Great Britain since 1960," in The Rise and Fall of Mass Marketing, eds. Richard S. Tedlow and Geoffrey Jones (New York: Routledge, 1993): 58-92.

${ }^{4}$ Roger Horowitz, Putting Meat on the American Table: Taste, Technology, Transformation (Baltimore: Johns Hopkins University, 2006).
} 
context in the early- to mid-twentieth-century United States, this paper also examines how business strategies helped shape, and were shaped by, cultural narratives about cellophane.

After examining the development of cellophane and of self-service operation, this paper concludes with consequences of this new merchandising system and of the increasing use of cellophane. Clear packages provided consumers with a new way of understanding product quality. Its transparency showed the insides of the package while shutting off consumers' access to the product through other senses. At supermarkets, where meat was already cut and bread packaged, and where consumers rarely had a chance to actually taste, smell, or touch foods, they needed to rely mostly on visual information in selecting products. Compared to goods sold in counter-service grocery stores at the turn of the twentieth century, cellophane-wrapped products sold in self-service stores a few decades later seemingly provided consumers with better visual information about goods.

However, the visibility supermarkets provided was carefully controlled by producers and retailers. ${ }^{5}$ Cellophane packaging enabled manufacturers to manipulate the appearance of products by controlling the amount of oxygen and moisture inside the package and preventing the discoloration of foods. As a result, with the advent of new technology and scientific knowledge, the freshness of foods became what geographer Susanne Freidberg calls "industrial freshness," engineered by producers, distributors, and retailers and presented in sanitized and standardized stores. ${ }^{6}$ Freidberg argues that producers' quest for manipulating fresh foods and consumers' demand for freshness "lies in the anxieties and dilemmas borne of industrial

\footnotetext{
${ }^{5}$ For broader discussion of the control of the color of foods, see Ai Hisano, "The Rise of Synthetic Colors in the American Food Industry, 1870-1940," Business History Review 90 (Autumn 2016): 483-504.

${ }^{6}$ Susanne Freidberg, Fresh: A Perishable History (Cambridge, MA: Belknap Press of Harvard University Press, 2009), 2.
} 
capitalism and the culture of mass consumption." As the market became distant from food producing sites, modern technologies, or what Leo Marx called "the machine in the garden," transformed agricultural production and the landscape in the American countryside, while urban consumers yearned for the "garden" in the city, specifically in the supermarket. ${ }^{8}$ Consumers' longing for "fresh," "natural" foods in a bright, clean store required retailers to prolong the shelflife of perishable products and to display them in a visually attractive manner.

\section{Before Self Service}

For much of the nineteenth century and the first decades of the twentieth, urban Americans bought food from public markets, local grocers, and peddlers, and picked produce from their own gardens. ${ }^{9}$ A public market was often a space of sensory chaos. In 1884, a newspaper reporter quoted a "commission-man" at the South Water Market in Chicago describing the market as a "maze of barrels and boxes and gory calves, and chicken-coops, redolent with the unmistakable odor of the badly kept country barnyard and huge piles of sacked potatoes, and egg-cases, squashes, barrels of cider, and hogs cold and stiff in death." ${ }^{\prime 10}$ Shoppers saw and touched produce, smelled combinations of different foods (and non-foods), and heard people talking and horses neighing. In local grocery stores, on the other hand, consumers' access to goods was relatively limited: products were often displayed behind the counter or stored in a backroom. $^{11}$

\footnotetext{
${ }^{7}$ Ibid., 3 .

${ }^{8}$ Leo Marx, The Machine in the Garden: Technology and the Pastoral Ideal in America (New York: Oxford University Press, 1964).

${ }^{9}$ Deutsch, Building, 13.

10 "The Marketing Problem," Chicago Tribune, December 28, 1884. See also Deutsch, Building, 24.

${ }^{11}$ Deutsch, Building; Mayo, The American Grocery Store, 43-75; and Strasser, Satisfaction Guaranteed, 58-88.
} 
Until the 1920s, although grocery stores had sold some perishable foods, their major food trade had been in canned and other processed products. Most butchers and produce grocers had traditionally operated specialized businesses in separate stores. In the 1920s, large independent grocers and chain stores began absorbing neighboring butcher shops and produce stores into their premises. In those "combined" stores that sold groceries as well as perishable foods, customers saved time by shopping for various food items at one store rather than at three different places. ${ }^{12}$ Among the major five departments in a supermarket - produce, meats, groceries, bakery, and dairy - the grocery department usually accounted for about half of the total store sales, generating the largest profit margin of the store. The contribution of produce and meat departments to store sales was relatively small: produce sales ranged from 8 to 20 percent, and meat department sales were approximately 25 to 30 percent of total store sales. ${ }^{13}$

Nevertheless, newly converted meat and produce sections became the "showcase" of the store because of their colorful "natural beauty" and the possibilities for attractive display. ${ }^{14}$ During the 1920s and 1930s, grocery manuals and trade journals repeatedly stressed the importance of fresh produce for supermarket businesses by claiming that perishable items made its "greatest single appeal to the consumer through the eye." ${ }^{\prime 15}$ A 1935 Progressive Grocer noted that no commodities "[lent] themselves more naturally to inviting, appetizing arrangements than do fresh fruits and vegetables." 16 In 1937, another article asserted that a "bountiful variety of fresh fruits and vegetables attractively displayed in all of nature's color and freshness" drew

\footnotetext{
12 Arieh Goldman, "Stages in the Development of the Supermarket," Journal of Retailing 51 (4) (Winter 19751976): 57; and Mayo, The American Grocery Store, 134.

${ }^{13}$ Edward A. Brand, Modern Supermarket Operation (New York: Book Division, Fairchild), 27, 29, 42; and Nelson A. Miller and Harvey W. Huegy, "Establishing and Operating a Grocery Store," U.S. Department of Commerce, Bureau of Foreign and Domestic Commerce, Industrial Series no. 21 (1946): 226.

${ }^{14}$ Brand, Modern Supermarket, 43.

15 “Trim Them Properly," Progressive Grocer 14, no. 2 (February 1935): 18.

16 “Give Produce Display Appetite Appeal," Progressive Grocer 14, no. 9 (September 1935): 44.
} 
consumers into the store. ${ }^{17}$ "Unusual freshness or superior appearance of products" could even justify higher pricing than other stores. ${ }^{18}$ Grocers believed that the appearance of displays was the most important factor in the moving of stocks of fruits and vegetables, and that the attractive display of agricultural produce influenced the ambience of the entire store. They hence arranged the produce section in the "best position" in the store - usually near the entrance. ${ }^{19}$

Even after this consolidation of grocery businesses, however, self-service was initially applied only to non-perishable packaged foods. The development of the first self-service store is attributed to Clarence Saunders's Piggly Wiggly stores, opened in 1917 in Memphis, Tennessee. During the 1920s and 1930s, grocers increasingly converted self-service retailing. Yet in most supermarkets, buying meat was much like shopping in a traditional butcher shop, with a fullservice counter staffed by male butchers and sales personnel. ${ }^{20}$ Shoppers lined up in front of the service counter and asked for the specific cut and the weight they wanted to purchase. During the transaction, customers had the opportunity to ask butchers which meat was fresh and whether it should be broiled or fried. The butcher retrieved the desired slab, cut the quantity ordered from the slab, and wrapped it. In purchasing produce, customers selected products from the bulk displays of fruits and vegetables, and store clerks working in the produce section weighed and bagged the items, then prices were confirmed by scale at the checkout counter. ${ }^{21}$

\footnotetext{
17 "Fruits and Vegetables Offer Best Chance to Draw Shoppers," Progressive Grocer 16, no. 1 (January 1937): 3839.

${ }^{18}$ Miller and Huegy, "Establishing and Operating," 227.

${ }^{19}$ Carl W. Dipman, Robert W. Mueller, and Ralph E. Head, eds., Self-Service Food Stores (New York: Progressive Grocer, 1946), 54; and Henry Frommes, “The 'Eye Appeal' in Selling,” Meat Merchandising 5, no. 12 (January 1930): 24. See also “Calls Color Secret of Fruit Display,” Progressive Grocer 16, no. 1 (January 1937): 135.

${ }^{20}$ A. M. Pearson, "Factors Indicative of Quality in Beef and Their Measurements" in Beeffor Tomorrow: Proceedings of a Conference, eds. E. R. Kiehl and Roland M. Bethke (Washington, D.C.: National Academy of Science, National Research Council, 1960), 37.

${ }^{21}$ Deutsch, Building, 69; Mayo, The American Grocery Store, 159; and "Produce Self-Service Successful," Progressive Grocer 24, no. 8 (August 1945): 140.
} 
The self-service merchandising of fresh meat was particularly slow to develop. Well into the 1940s, service-type meat departments were the rule and not the exception even in supermarkets. Supermarket executives were reluctant to sell meat the same way they sold groceries. They generally believed that it would be impossible to adapt self-service to an item like fresh meat requiring so much personal service. ${ }^{22}$ In 1948, only 39 percent of the independents and 56 percent of the chain grocers were on a complete self-service basis. ${ }^{23}$ Changing over to complete self-service meats was considerably more complicated and costly than to self-service groceries. Those independent stores who offered delivery service were much less interested in complete self-service of meat.

\section{Challenges to Self Service}

Supermarket managers showed tremendous interest in self-service retailing of perishable items, particularly meats. They considered the counter-service meat department the bottleneck for their businesses. Especially on weekends, customers made a long line at the checkout counter, slowing down store operation. However, only a few stores tried running meat departments on a self-service basis before the 1940s. ${ }^{24}$ The H. B. Bohack Company of New York experimented with self-service in its fifty stores in 1927. Its experiment failed, however. These stores lacked adequate refrigerated display cases and sufficient display space. The wrapping materials then available were not satisfactory for self-serve meat: they did not maintain the color and were not transparent - the feature that most retailers considered essential for self-service. In addition, most consumers had yet to become acquainted with self-service shopping in general. ${ }^{25}$ California-

\footnotetext{
22 "Self-Service for Meat Uncorks Super-Market Bottleneck," Meat Merchandising 17, no.9 (September 1941): 24.

23 "Self-Service Meats," Meat Merchandising 24, no.8 (August 1948).

${ }^{24}$ See "Self-Service for Meat Uncorks," 24; and "Self-Serve Meats," Meat Merchandising 18, no. 5 (May 1942 ): 66.

${ }^{25}$ Brand, Modern Supermarket, 32.
} 
based Espandola tried self-serve meat in the 1930s. The store's butchers cut meats and wrapped them in opaque butcher paper in advance. After weighing the package and designating its price, the meat was placed in a self-service refrigerated dairy case. Although the packages were accessible, customers could not see the meat, and the sales of the self-serve meat were not satisfactory to the store. During the 1930 s, other food retailers experimented but soon gave up their self-service meat operation.

Limitations on the availability of packaging materials was the primary limit on expansion of self-service operation. ${ }^{26}$ One of the problems that food retailers faced was the discoloration of meat once packed for self-service. ${ }^{27}$ Meat packers and food retailers described the scarlet red color of meat as "bloom," which consumers generally considered as a sign of good, fresh meat. But this "fresh" red color did not actually indicate that the meat was the "freshest" in terms of the time it was exposed to the air. Since meats were perishable foods, with colors subject to change, keeping the desired color was a major objective. ${ }^{28}$ A packaging material for self-service fresh meat needed to possess properties that preserved color and were mechanically strong without imparting any harmful substance to the meat. ${ }^{29}$ Because discoloration was a major salability of prepackaged meats, it has been given considerable attention by meat packing companies, grocery stores, and packaging companies. Three-fourths of the retailers reported that fresh beef, veal,

\footnotetext{
${ }^{26}$ Francis E. Simmons, "Packaging Aids to Marketing," Journal of Marketing 13, no. 4 (April 1949): 514.

${ }^{27}$ A. T. Edinger, "Prepackaged Meat Sells Itself," U.S. Department of Agriculture, Production and Marketing Administration, Marketing Activities 13, no. 1 (January 1950): 6; "Here Are Facts on Color Changes," National Provisioner 143, no. 27 (December 31, 1960); Pearson, "Factors Indicative of Quality," 37; and Gordon L. Robertson, Food Packaging: Principles and Practice (New York: Marcel Dekker, 1993), 433.

${ }^{28}$ DuPont, "Color Sells Prepackaged Meats," Packages and People 15, no.3 (1951), box 1, DuPont Film Department Collection (Accession 2168) (hereafter DPFD), Hagley Museum and Library (hereafter HML), Wilmington, DE.

29 "Here Are Facts on Color Changes."
} 
pork and lamb remained in an acceptable condition in display cases for 48 hours, and in rare cases up to 72 hours. $^{30}$

The color of cut meat depends chiefly on the relative amounts of the three pigment derivatives of myoglobin present at the meat surface: reduced myoglobin (Mb), oxymyoglobin $(02 \mathrm{Mb})$, and metmyoglobin (MetMb). The amount of oxymyoglobin in the meat determines the color of the meat itself, which ranges from a bright red for beef to a delicate pink for veal and pork. ${ }^{31}$ In uncut beef, myoglobin exists as a purple-red compound called "reduced myoglobin," which has a great affinity for oxygen particularly at the low oxygen pressures. When meat is first cut, because reduced myoglobin predominates on the surface, meat looks purple. After the meat is exposed to air for 15-30 minutes (depending on temperature), oxygen is added to reduced myoglobin, which becomes a scarlet-red pigment called "oxymyoglobin"; hence the outer most layer exposed to air becomes the bloom color of "fresh" meat.

When the supply of oxygen is cut off, oxymyoglobin becomes a brown substance called "metmyoglobin." Metmyoglobin first exists between the red and purple regions as a thin brown layer near the surface of meat. This brown layer thickens within one to two days and becomes apparent on the surface, darkening the meat. Generally this brown color is a surface reaction, although in some instances it may penetrate as much as $1 / 4$ inch deep. ${ }^{32}$ Although brown meat was

\footnotetext{
${ }^{30}$ Edinger, "Prepackaged Meat Sells Itself," 5.

${ }^{31}$ Jerry Lee Mautz, "A Discussion of the History and Development of the In-Store Merchandising and Packaging of Fresh Red Meat with Emphasis on the Effect of Polyvinyl Chloride Film on a Traditional Cellophane Market," Master's Thesis, Michigan State University, 1966.

Differences in color intensity between species are primarily caused by differing concentrations of myoglobin. Thus beef which has the highest concentration is the darkest of the meat species, with lamb being intermediate in color and myoglobin concentration. Pork has the lowest concentration of myoglobin and as such is the lightest in color. Male animals usually produce darker meat than females due to a greater concentration of myoglobin in meat derived from male animals. Robertson, Food Packaging, 435, 438

32 "Problems in Packaging Meat Products," National Provisioner 114, no.16 (April 1946).
} 
still good enough to eat for a short time, further exposure to oxygen would quickly spoil the meat by bacterial action without causing any further color change. ${ }^{33}$

A number of factors affected the rate at which the bloom was lost, including temperature, bacteria, and oxygen availability. Light intensity, type of packages, and the variety of the meat also determined how fast the product discolored. It was hence extremely difficult for meat packers and retailers to predict the exact color effect of any particular treatment on a piece of meat. ${ }^{34}$ Among these variables, temperature and oxygen were critical factors in maintaining bloom. High storage temperature accelerated the color change from red to brown on the surface of meat. ${ }^{35}$ According to one experiment conducted in the mid-1950s, the red color of beef steaks could be kept up to seven days at $28^{\circ} \mathrm{F}$, but held only one day at a temperature of $50^{\circ} \mathrm{F}^{36}$ The growth of bacteria, which caused the discoloration of meat, also depended on temperature. Strict controls on both refrigeration and sanitation were hence essential to retard bacteria growth in cut meats and prolong bright red color. ${ }^{37}$ These various inter-related factors of meat discoloration made it difficult for retailers and package companies to develop the self-service retailing of meat.

The development of refrigerated display cases gave the impetus to successful merchandising of perishable foods, especially meat. Commercial refrigerators became available in the 1910s. They were equipped with large tanks of cracked ice and salt to keep foods cold. These display cases took store space and their price was high, hence were not suited to small

\footnotetext{
${ }^{33}$ Wilmer A. Jenkins and James P. Harrington, Packaging Foods with Plastics (Lancaster, PA: Technomic, 1991): 110 .

${ }^{34}$ David A. Fellers, “Pair Testing' Compares How Films Maintain Color of Fresh Meat,” Package Engineering 10, no. 6 (June 1965): 92; and Robertson, Food Packaging, 435.

${ }^{35}$ Robertson, Food Packaging, 437.

36 “Oxygen Control Key to Fresh Meat Color," National Provisioner 132, no. 7 (February 12, 1955). See also C. B. Thor and F. Warren Tauber, "New Ideas on Developing Packaging Films for Cured and Fresh Meats," National Provisioner 133, no. 11 (November 10, 1955): 23, 25-26.

${ }^{37}$ Mautz, “A Discussion,” 30-32; and Robertson, Food Packaging, 438.
} 
grocery stores ${ }^{38}$ In the mid-1920s, the Frigidaire Company developed refrigerated coils, as a substitute for the cracked-ice and salt tank. This eliminated all the waste space for bunkers, ice, and salt. ${ }^{39}$ In the late 1930s, the Great Atlantic \& Pacific Tea Company (A\&P), a leading American chain store, pioneered the self-service refrigerated meat case. A\&P's engineers converted a fish and delicatessen case into a usable meat case. Equipment manufacturers modified A\&P's improvised case, and began manufacturing refrigerated display cases designed for self-service meat by the 1940s. ${ }^{40}$ They pitched the visual appeal and freshness of meat that their refrigerators provided. "[Consumers] see what they want and buy what they see!" - one of the leading display case manufacturers, Hussmann, advertised, stressing visibility as a key to successful meat merchandising. ${ }^{41}$

When A\&P opened its first "self-service" meat departments in four of its stores in June 1941, the news "spread like wildfire" among grocers in the northeastern states. ${ }^{42}$ It was initially a combination of service-type and self-service merchandising. In each store, butchers cut, weighed, packaged, and priced meats in a back room in anticipation of the day's sale, and displayed the packaged meat in self-service cases. A clerk was responsible for servicing the "self-service" case to supervise the products and consult with consumers who were not used to buying self-serve meat. ${ }^{43}$ The new operation was relatively successful, increasing meat sales in the experimental stores by about 30 percent. ${ }^{44}$

\footnotetext{
${ }^{38}$ Andrew D. Althouse and Carl H. Turnquist, Modern Electric and Gas Refrigeration, 4th ed. (Chicago: GoodheartWillcox, 1944), 361-63.

${ }^{39}$ M. M. Zimmerman, The Super Market: A Revolution in Distribution (New York: McGraw-Hill, 1955), 154-55.

${ }^{40}$ Brand, Modern Supermarket, 32; and Mayo, The American Grocery Store, 159.

${ }^{41}$ Allied Store Utilities Company, HUSSMAN Advertisement, Meat Merchandising 16, no. 7 (July 1940): 32-33. See also C. V. Hill \& Company Advertisement, Progressive Grocer 20, no. 5 (May 1941): 28; Ed Friedrich Sale Corp. Advertisement, Progressive Grocer 20, no. 7 (July 1941): 3; and Super-Cold Advertisement, Progressive Grocer 24, no. 5 (May 1945): 183.

${ }^{42}$ Remus Harris, "Self-Service Meats Are Introduced by A\&P," Progressive Grocer 20, no. 6 (June 1941): 46.

${ }^{43}$ Ibid., 46-69. See also Zimmerman, The Super Market, 61.

${ }^{44}$ Mayo, The American Grocery Store, 159.
} 
Until the post-war period, however, refrigeration cases were ineffective in cooling foods for complete self-service operation, although they helped grocers prolong the shelf life of produce and meat relatively longer than before. Retail stores generally utilized open display refrigeration cases to display their pre-cut meat. These cases did not maintain low enough temperature. ${ }^{45}$ Two layers of packaged meats were ideal for refrigeration in self-service open display cases because the temperature of $35^{\circ} \mathrm{F}$ could be maintained. On busy days, however, grocers piled the meats in three or four layers. Unless the meats moved quickly, the height of the packaged meats raised the temperature to 45 to $50^{\circ} \mathrm{F}$ in the top two layers, resulting in discoloration and shrinkage. To prevent the deterioration of meat color, clerks needed to rotate the packages; the self-service meat department hence required constant supervision. ${ }^{46}$ One grocery owner noted in the mid-1940s that until "properly refrigerated transportation and display equipment is available, peak 'farm-to-table' freshness cannot be maintained." ${ }^{, 47}$

While A\&P's first self-service meat department was relatively successful compared with earlier ones, the leading chain store still faced the problem of meat discoloration. Store clerks constantly watched over display cases and removed discolored meat from the case. Grocers needed, in addition to adequate refrigerated cases, a packaging material that preserved color and was mechanically strong enough to protect the meat. ${ }^{48}$

\section{The Development of Cellophane}

Swiss textile engineer Jacques Brandenberger invented the first transparent film in 1908. He created cellulose film derived from wood pulp (cellulose), and named it "cellophane" from

\footnotetext{
${ }^{45}$ Mautz, "A Discussion,"16.

${ }^{46}$ Harris, "Self-Service Meats," 46, 61.

${ }^{47}$ Albert Eisner, Jr., "What We Have Learned about Prepackaged Produce," Chain Store Age 22 (October 1946).

${ }^{48}$ DuPont, "Color Sells Prepackaged Meats."
} 
the words cellulose and diaphane ("transparent"). In 1917, Brandenberger assigned his patents to La Cellophane Société Anonyme, a new French company formed to commercially promote his invention. By 1922, out of 400 tons of cellophane manufactured in France, nearly 40 percent was sold in the American market. In 1923, La Cellophane licensed to DuPont the exclusive rights to manufacture and sell cellophane in the United States. DuPont was engaged in the cellophane business through its subsidiary, DuPont Cellophane Company, in which DuPont held 52 percent interest and La Cellophane held the rest of its interest. In April 1924, the first DuPont cellophane was made in a new plant at Buffalo, New York, and the firm later added three more plants for cellophane production in Old Hickory, Tennessee; Richmond, Virginia; and Clinton, Iowa. ${ }^{49}$ Cellophane was the earliest transparent packaging material used for foods. Yet its sales and use were initially limited, used primarily to over-wrap boxes and cartons of such goods as candy, perfume, and cigarettes. Although the film was water proof, it was not moisture proof and not useful for direct packaging of many food products. After DuPont chemists developed moisture-proof cellophane in 1927 , food manufacturers began using the film for packaging various products, including baked goods, cheese, sliced bacon, hams, sausages, and other cured meat products. As a result, cellophane sales tripled between 1928 and $19300^{50}$

The moisture proof cellophane, however, was brittle and nondurable at low temperatures, and hence not well suited for refrigerated display cases, such as self-service meat display. ${ }^{51}$ For meat packaging, grocers needed a material that preserved color and was mechanically strong

\footnotetext{
${ }^{49}$ George W. Stocking and Willard F. Mueller, "The Cellophane Case and the New Competition," American Economic Review 45, no. 1 (March 1955): 22-23; C. H. Ward-Jackson, The "Cellophane" Story: Origins of a British Industrial Group (Edinburgh, UK: William Blackwood, 1977), 37; and United States v. E. I. du Pont de Nemours \& Co., 118 F. Supp. 41 (1953). See also E. I. du Pont de Nemours \& Co. v. Sylvania Industrial Corporation, 122 F.2d 400 (1941).

${ }^{50}$ David A. Hounshell and John Kenly Smith, Jr., Science and Corporate Strategy: Du Pont R\&D, 1902-1980 (New York: Cambridge University Press, 1988), 170. See also John M. Ramsbottom, "Some Aspects of Meat Packaging," in New Potentials in Consumer Packaging, ed. M. J. Dooher (New York: American Management Association, 1955), 14.

${ }^{51}$ Mautz, “A Discussion,” 45-46.
} 
enough to protect the meat. ${ }^{52}$ To prolong meat's red color, the outer wrapper had to permit the free passage of oxygen to the surface of the meat. While excessive moisture loss should be avoided, the surface of the meat must be relatively dry to impede mold growth. Packaging materials also needed to be relatively inexpensive ${ }^{53}$ Due to inadequate moisture control inside the package, fresh meat often discolored after several hours after it was packaged. Discoloration occurred on the bottom of meat where it rested upon cellophane (grocers usually wrapped meat directly in cellophane at the time) ${ }^{54}$ In fact, when A\&P first started its self-service operations in 1941, the store used cellophane to provide visibility to shoppers, and inserted a sheet of waxed paper between the meat and the film to prevent discoloration. ${ }^{55}$ In addition, meat retailers believed that transparency was "mandatory" in self-service meat display as the package was "the salesman" and the shopper could purchase foods without the "intervention" of store clerks. ${ }^{56}$ Transparent films manufactured prior to the mid-1940s were not equipped with all these qualities necessary for wrapping meat for self-service merchandising.

In the 1930s, other chemical companies began expanding their transparent packaging businesses. Sylvania Industrial Corporation of America started to manufacture plain cellophane under a Belgian patent in $1930 .{ }^{57}$ In the following year, the company started the production of moisture-proof cellophane under its own methods. DuPont sued Sylvania for patent infringement, and in 1933, after negotiations over patent rights, DuPont licensed Sylvania to manufacture and sell moisture-proof cellophane produced under the DuPont patents at a royalty of 2 percent of sales. The rate was to increase by 1 percent until it reached 29 percent in 1942 . The contract also

\footnotetext{
${ }^{52}$ DuPont, "Color Sells Prepackaged Meats."

53 "Problems in Packaging Meat Products"; "Maximum Salable Life for Fresh Meats Can Be Achieved by Use of Proper Packaging Materials and Methods," National Provisioner 134, no. 15 (1956): 34.

54 "Self-Service for Meat Uncorks," 24.

55 "How the A\&P Packages Meat for Self-Service," Progressive Grocer 20, no. 7 (July 1941): 58-59.

56 "Problems in Packaging Meat Products."

${ }^{57}$ Sylvania first started the manufacturing of plain cellophane in 1930, under a Belgian patent, held by Société Industrielle de la Cellulose (SIDAC).
} 
required that sales of moisture-proof cellophane by Sylvania be restricted to 20 percent of the two companies' combined sales of moisture-proof cellophane (this limiting clause was dropped in 1945). ${ }^{58}$ Although the production and sale of cellophane by Sylvania gradually increased after 1933, due to this 20 percent limiting clause, the company was not a greatest competitor for DuPont, which could still maintain $80 \%$ share of the moisture-proof cellophane market. ${ }^{59}$ Other transparent films included Goodyear Tire's Pliofilm, Dow Chemical Company's Saran, and Dewey and Almy Chemical Company’s Cry-O-Rap. Until the 1950s, however, DuPont managers did not view these other transparent films as significant competitors. ${ }^{60}$ According to a 1949 study, of the total amount of transparent packages, cellophane accounted for about 87 percent. DuPont's cellophane, including both moisture-proof and other types, amounted to 78 percent of the all cellophane produced and imported. ${ }^{61}$ Saran was superior in moisture protection, but significant commercial uses had not been developed. Pliofilm was a rubber-based film and was highly transparent, like cellophane, and superior to cellophane in moistureproofness and resistance to tearing. But due to its higher price, the sale of Pliofilm remained smaller than cellophane sale: in 1939, Pliofilm sales was only 2 percent of cellophane sales; by 1949 they had increased to only 4.4 percent. ${ }^{62}$ Another competitor, cellulose acetate, which appeared in 1931, was also highly transparent. But it was not moisture-proof. By 1949, the sales of cellulose acetate was only 3.7 percent of cellophane sales. ${ }^{63}$

\footnotetext{
${ }^{58}$ Sylvania paid DuPont approximately $\$ 1,500,000$ in royalties under the 1933 Agreement during its effectiveness from April 1933 to January 1, 1945. In 1946, Sylvania was acquired by the American Viscose Corporation with assets of over two hundred million dollars. 118 F. Supp. 41, no.2, p.31-36; 351 U.S. 377, p.16; and Stocking and Mueller, "The Cellophane Case," 43.

59351 U.S. 377, p.12, 14.

${ }^{60}$ Stocking and Mueller, "The Cellophane Case," 49

${ }^{61} 118$ F. Supp. 41, p.110-111; and 351 U.S. 377, p.26.

${ }^{6} 118$ F. Supp. 41, no.1, p.27; 351 U.S. 377, p.23; and Stocking and Mueller, "The Cellophane Case," 48-49.

${ }^{63}$ Stocking and Mueller, "The Cellophane Case," 49.
} 
More daunting was competition with manufacturers who produced other flexible packaging materials, both transparent and non-transparent, such as waxed papers and glassine. There were generally four categories of flexible packaging materials: (1) opaque, non-moistureproof wrapping paper, such as parchment and kraft papers; (2) moisture-proof films of varying degrees of transparency, such as waxed papers, moisture-proof cellophane, polyethylene, Saran, and Pliofilm; (3) non-moisture-proof transparent films, such as cellulose acetate and plain cellophane; and (4) moisture-proof materials other than films of varying degrees of transparency, such as foils and paper products. Papers, such as kraft papers, glassine, and parchment papers, were used for wrapping various foods more often than cellophane, as they were cheaper than transparent films. These papers were used nearly 89 percent of baked goods, 46 percent of fresh produce, and 57 percent of meat in $1949 .{ }^{64}$ In the same year, transparent films, including cellophane and other clear films, remained less than 30 percent of total amounts of flexible packaging materials produced in the United States and imported to the nation. ${ }^{65}$

When cellophane was first made by DuPont, wax paper, glassine, and sulphite paper were the major flexible packaging materials in use. ${ }^{66}$ Cellophane was usually more expensive than the two largest selling flexible packaging materials, wax paper and glassine. From 1924 to 1932, DuPont dropped the price of plain cellophane 84 percent, while the price of glassine remained constant. The ratio between moisture-proof cellophane prices and glassine prices, and between moisture-proof cellophane and waxed paper prices, diminished during 1929-1949. In 1929, the price of cellophane was seven times that of glassine. In 1949, moisture-proof cellophane price was roughly twice that of glassine. ${ }^{67}$ As its sales increased and the use expanded, DuPont

\footnotetext{
${ }^{64} 118$ F. Supp. 41, p.113-14.

${ }^{65}$ Ibid., p.110-111; and 351 U.S. 377, p.26.

${ }^{66} 118$ F. Supp. 41, p.23.

${ }^{67}$ Ibid., 66.
} 
lowered its price from $\$ 1.74$ a pound in 1925 to less than $60 \notin$ in $1935 .^{68}$ By 1949 , among all flexible materials produced, cellophane accounted for about $20 \%$ of packaging materials used for foods in the mid-twentieth century. ${ }^{69}$

\section{Marketing Cellophane: Better Visibility and Modernity ${ }^{70}$}

In promoting the use of cellophane for food businesses, DuPont stressed better visibility as the most important factor in selling foods. DuPont published a number of market studies reporting that many shoppers made purchasing decisions in the store on impulse. One of DuPont's research concluded that 85 percent of all food purchase was done by the eye. ${ }^{71}$ The company's another study, conducted in 1937, reported that 90.9 percent of consumers surveyed made impulse purchases because they saw the products in stores. ${ }^{72}$ Believing in such data, food retailers stressed the significance of visually focused marketing to appeal to the desires of shoppers. DuPont also claimed that cellophane helped increase the sales of food products. In 1932, the firm reported that the sales of cellophane-packaged pound cake increased 60 percent. $^{73}$ There was 55 percent increase in the sales of crackers, when wrapped in cellophane. ${ }^{74}$

DuPont managers argued that vision was the most effective way to sell foods because consumers understood food quality based on visual information. Although consumers often wanted also to touch and smell such foods as meat, bread, and produce to judge product quality, DuPont, as well as food marketers and retailers, constructed vision-centered discourse in food

\footnotetext{
${ }^{68}$ DuPont, "ANSWERS about Du Pont Cellophane," n.d., box 1, DPFD, HML; and "Just About All About Cellophane," Fortune (February 1932): 76.

${ }^{69} 118$ F. Supp. 41, p.113-14.

${ }^{70}$ For further discussion on this topic, see Ai Hisano, "Selling Food in Clear Packages: The Creation of a New Visual Regime," International Journal of Food Design (forthcoming).

${ }^{71}$ DuPont, "Cellophane: Modern Merchandising Aid" (1928), Published Collections Department, HML.

${ }^{72}$ DuPont, "Impulse Buying” (1937), box 46, DuPont Advertising Department Records (Accession 1803) (hereafter DPAD), HML.

${ }^{73}$ DuPont, "Cellophane Brings 60\% Increase in Pound Cake Sales," Bulletin 17-HH (1932), box 45, DPAD, HML.

${ }^{74}$ DuPont, “A New Series of Retail Store Tests" (1932), box 45, DPAD, HML.
} 
retailing. ${ }^{75}$ Through cellophane, "every detail of color, size, shape and texture [was] clearly apparent," contended DuPont's 1928 brochure for cellophane. ${ }^{76}$ DuPont's advertisement featured in a 1930 confectioners trade journal likewise stated that "your EYES can TASTE Cellophanewrapped candy." ${ }^{, 77}$ The appearance of food was expected to convey sensory knowledge that consumers understood, and helped them imagine, the taste, smell, and texture of a product.

The sight of food wrapped in cellophane became a part of colorful packages. In using cellophane for a butter package, for example, a DuPont manager contended that "the rich yellow of the butter itself form[ed] a splendid background for a colorful design.,"78 The combination of package color and product color was significant in selling products. To appeal to consumers' eyes, the "color of the product must be considered in the overall color design," noted a 1950 DuPont pamphlet. ${ }^{79}$ Cellophane transformed not only how consumers purchased foods and understood their quality, but also how food producers and film makers designed food packages.

This creation of vision-centered food shopping experiences and retailing environments rested on a gender-biased understanding of shopping patterns and sensory perception. In a 1931 grocers' manual, its author argued that the woman's sensory perception was "more keenly developed than the man's." ${ }^{80}$ Similarly, a 1937 grocery trade journal asserted that "she buys meat with her eyes. ${ }^{\prime 81}$ These statements and advertisements reflected the contemporary understanding of food shoppers whom grocers generally believed to be women. Such gendered narrative about

\footnotetext{
${ }^{75}$ Ernest Dichter, “An Exploratory Psychological Study of Consumer Reactions to Cellophane and Wax Paper Wrapped Bread" (1947), Ernest Dichter Papers (Accession 2407) (hereafter EDP), HML; and Carl W. Dipman, ed., The Modern Grocery Store (New York: Progressive Grocer, 1931).

${ }^{76}$ DuPont, "Cellophane."

${ }^{77}$ DuPont Advertisement, Manufacturing Confectioner (1930), box 43, DPAD, HML [emphasis in original].

${ }^{78}$ DuPont, "Printed Butter Wrap Samples," Bulletin 122-JJ (1934), box 45, DPAD, HML.

${ }^{79}$ DuPont, "Color: A Signal for Store Traffic," Packages \& People 14, no. 3 (1950), box 1, DPFD, HML.

${ }^{80}$ Dipman, The Modern Grocery Store, 8.

${ }^{81}$ Craig Davidson and Hugo B. Snider, "She Buys Meat with Her Eyes," Progressive Grocer 16, no. 5 (May 1937): 32-33.
} 
food purchasing and visuality influenced ways food company managers and packaging manufacturers marketed their products.

DuPont stressed the importance of visibility not only to grocers but also to consumers specifically female shoppers. The firm's cellophane advertisements, published in women's magazines and other popular publications during the 1930s and 1940s, often stressed the importance of vision in purchasing food by claiming, for example, "see what you buy" and "eye it before you buy it" (Figure 1). ${ }^{82}$ These advertisements commonly featured eyes of women. The illustration of the eyes as well as the advertising rhetoric in the text helped promote the importance of appearance in selecting foods. DuPont's cellophane advertisements also stressed the economical advantage of the product. Because cellophane kept the content fresh and clean, the firm suggested, there was less waste. One of the advertisements noted that those who chose cellophane packaged products were "smart shoppers," suggesting that cellophane helped housewives to achieve "scientifically" managed food purchasing. ${ }^{83}$

Buying through the eyes was not only a "smart" way but also a modern way of buying foods. In self-service supermarkets, bright, well-organized interiors and equipment, including electricity, refrigeration, and cash registers, served to "recast the cultural role of the grocery store as an emblem of modernity." ${ }^{84}$ In addition, the elimination of objectionable odor and the emphasis on vision, as well as store interior, represented modern shopping. A 1939 grocery trade journal article argued that for a modern supermarket, grocers must eliminate "smelly, messy,

\footnotetext{
${ }^{82}$ See for example DuPont Advertisements, Saturday Evening Post (1945) and Life (1945), both in box 43, DPAD, HML.

${ }^{83}$ DuPont Advertisement, Saturday Evening Post (1948) in box 43, DPAD, HML.

${ }^{84}$ Lisa C. Tolbert, "The Aristocracy of the Market Basket: Self-Service Food Shopping in the New South," in Food Chains: From Farmyard to Shopping Cart, eds. Warren Belasco and Roger Horowitz (Philadelphia: University of Pennsylvania Press, 2009), 183.
} 


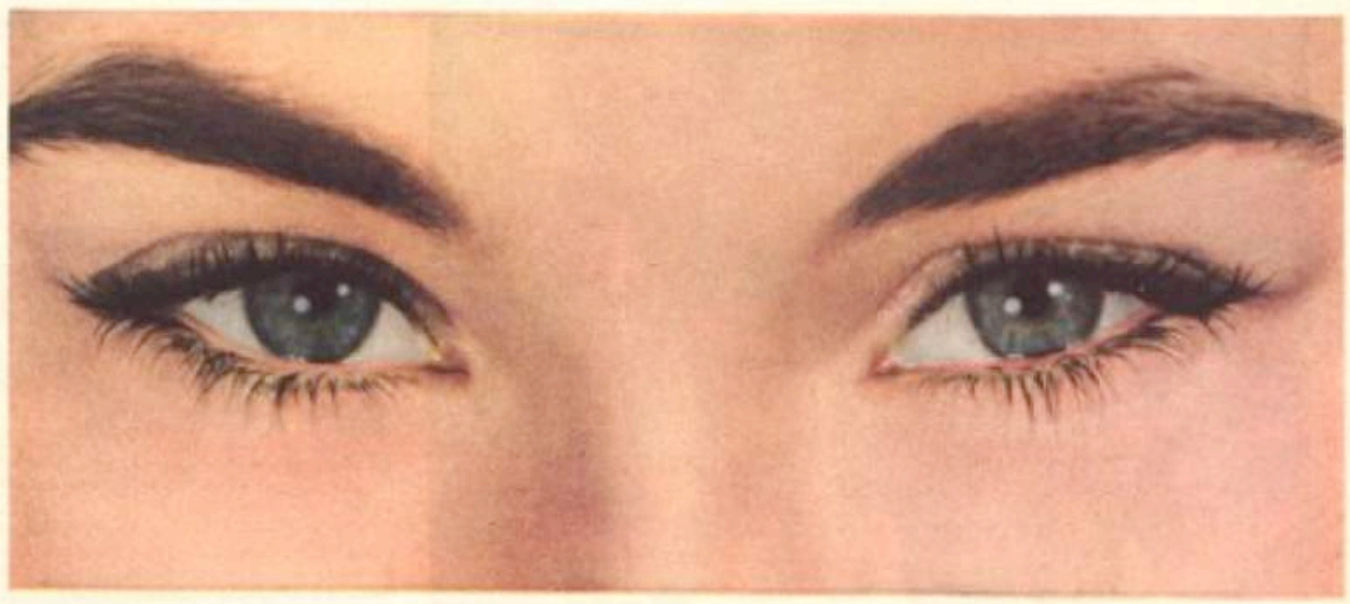

\section{$\Lambda$ thrifty rule: EYE IT before you BUY IT}

\section{CELORHANt WIL SOON at EACK TO HELP THEITYY SHOPPES}

Durine the yar Cellophane served to reniect vital supplies of our arenod forces. That's why the civilisn supply is limited, and why there hawe been fewer Celboglane-wrapped peodact en stove caunters.

However, thrifiy shoppers realixe more than ever that they suve money and hele avoid disappoint. ment if thoy ent we what they bery. Transparest Du Pent Celloptase has made it preailile for mer. chants to shew the mod quality af their pexilectshas uphald the custamer's right of inspection.

When you shep lodsy, yov may not find frosh vegetables, for inatanos, on display in transparent Crlloghane packages. But woon yvu probably will be ahle to get s wide variety of ethoicent food products - with their llrenheses peotected hy meisturepecol De Pent Cellophuse. Again, you'll be able te ege eoch product beforeyou hruy it - becouse Cellophane shous what it procers.

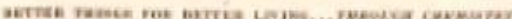

A product of Du Pent research

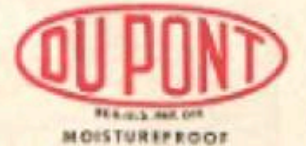

Cellophane

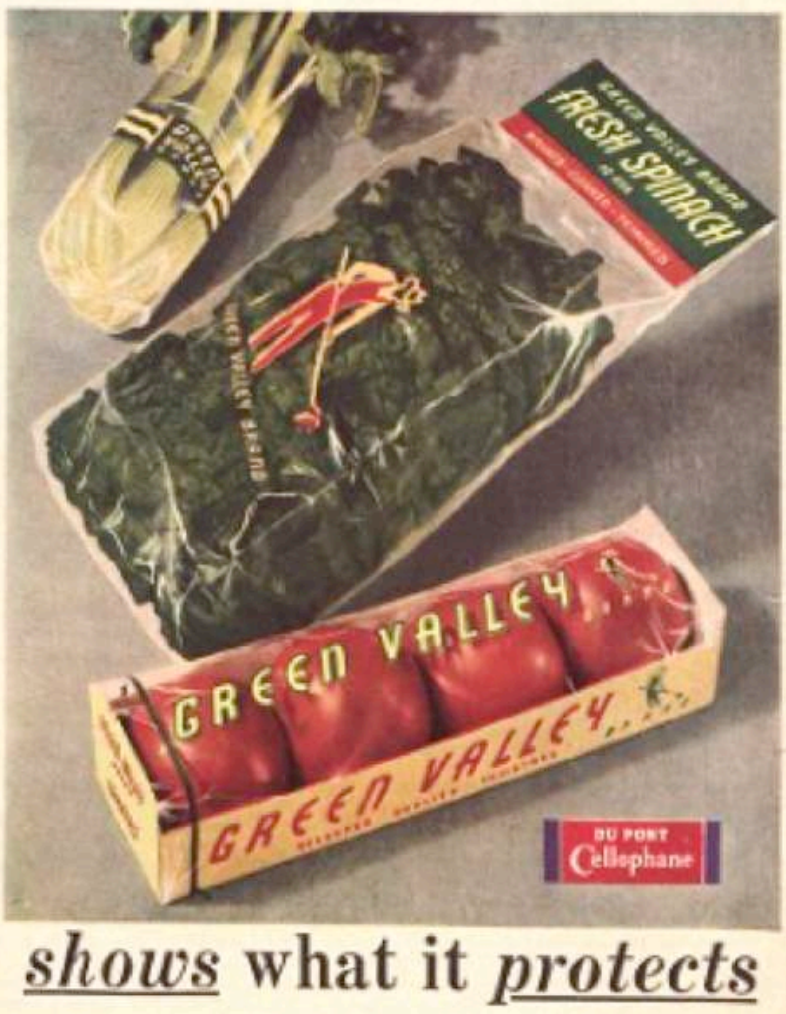

Figure 1: Advertisement for DuPont Cellophane, Saturday Evening Post, 1945, dpads_1803_00590, Series 1, Box 43, Folder 23, DuPont Advertising Department records (Accession 1803), Manuscripts and Archives Department, Hagley Museum and Library, Wilmington, DE. 
unsanitary-appearing" products. ${ }^{85}$ Cellophane helped grocers to display, for example, fish "without danger of imparting a "fishy' odor" to other products. ${ }^{86}$

Cellophane itself embodied this ideal of sanitation and cleanliness as "the modern, scientific wrapping material." ${ }^{87}$ In the first decades of the twentieth century, there was the rising concern over sanitation, cleanliness, and bodily hygiene, often advocated by progressive health reformers, in the United States. ${ }^{88}$ Seeking to appeal to consumers' desire for an ideal modern life, DuPont stressed that cellophane was "germ proof" and protected the content from dirt. ${ }^{89}$ The “modern" packaging film materialized the ideal of cleanliness and sanitation.

As cellophane became a symbol of modern living, it became a popular icon in the 1930s. It was featured in New Yorker cartoons, films, songs, and a book like Virgins in Cellophane: From Maker to Consumer Untouched by Human Hand, written by Bett Hooper in $1932 .^{90}$ Hooper's book title eloquently indicated the materiality and cultural significance of cellophane. Cellophane could prevent people from touching the content, which would hence remain pure and clean. The film, as the title suggests, served as a mighty barrier that protected the virginity and purity of the content (either food or a woman), shutting out not only dirt and germ but also unwanted human touch.

As the use of cellophane became expanded, consumers increasingly came to encounter this new film in their everyday shopping. According to a 1947 market study, conducted by

\footnotetext{
85 "Food Shoppers and Food Selling: Yesterday and Today," Progressive Grocer 18, no. 4 (April 1939). See also "Cleanliness in the Market," Meat Merchandising 2, no. 8 (August 1926): 8.

86 "Food Shoppers and Food Selling."

${ }^{87}$ DuPont Advertisement, Saturday Evening Post (1929) in box 43, DPAD, HML.

${ }^{88}$ For the history of ideas about sanitation and cleanliness in the Progressive-Era America, see Cynthia Lee Henthorn, From Submarines to Suburbs: Selling a Better America, 1939-1959 (Athens, OH: Ohio University Press, 2006); and Ellen Lupton and J. Abbott Miller, The Bathroom, the Kitchen, and the Aesthetics of Waste: A Process of Elimination (Cambridge: MIT List Visual Arts Center, 1992).

${ }^{89}$ DuPont Advertisement, Saturday Evening Post (1933) in box 43, DPAD, HML.

90 Judith Brown, Glamour in Six Dimensions: Modernism and the Radiance of Form (Ithaca: Cornell University Press, 2009), 145-72; and Tom Fisher and Janet Shipton Designing for Re-Use: The Life of Consumer Packaging (London: Earthscan, 2009), 50-51; and Bett Hooper, Virgins in Cellophane: From Maker to Consumer Untouched by Human Hand (New York: Ray Long \& Richard R. Smith, 1932).
} 
Ernest Dichter, a leading market researcher in the United States, consumers generally showed their preference for cellophane because the film "[kept] things clean and sanitary, protect[ed] the freshness and flavor of foods and, most important of all, [let them] see what [they] buy." ${ }^{91}$ Yet cellophane was still an unfamiliar material to many consumers. Dichter's another 1947 market research noted that his respondents conceived of cellophane as "artificial sickness" of the machine age. ${ }^{92}$ Dichter proposed to his client that "a homey-looking stamp" could be embossed on a cellophane wrapping to alleviate its strangeness. ${ }^{93}$ His observation suggests that grocers needed to domesticate this modern material with something that would invoke familiarity, such as 'a homey-looking stamp,' in order to gain consumer acceptance. DuPont's advertisements and other promotion tools also helped familiarize modern science and materials, facilitating consumers' acceptance of new development. Promotion rhetoric of cellophane associated the film with personal hygiene and the management of family budget, helping to incorporate it into housewives' everyday lives. ${ }^{94}$

\section{The Increase of Self Service}

While promoting the advantage of using cellophane, DuPont repeatedly advocated the benefit of self-service merchandising during the 1930s and 1940s. The company published a number of market studies and pamphlets for grocers and food businesses, such as "Merchandising Trends in Fresh Fruits and Vegetables" and "Self-Service Meats: Progress Report on a Promising New Development.” Through these publications, the firm sought to

\footnotetext{
${ }^{91}$ Ernest Dichter, "Cellophane and the Consumer" (1947), EDP, HML.

${ }^{92}$ Dichter, "An Exploratory Psychological Study."

${ }^{93}$ Ibid.

${ }^{94}$ See Jeffrey L. Meikle, American Plastic: A Cultural History (New Brunswick, NJ: Rutgers University Press, 1995); and Kristina Wilson, Livable Modernism: Interior, Decorating and Design during the Great Depression (New Haven: Yale University Press, 2004).
} 
convince store operators to adopt self-service merchandising, which DuPont believed would increase the sales of cellophane. ${ }^{95}$ The firm's executives also stressed to its employees that they should be aware of their mission of expanding self-service. Its in-house letter, issued by the Cellophane Division, noted:

The distribution of many food manufacturers is still entirely through service stores. However, we can point out to those manufacturers that the principle of self-service, i.e., open display, is trickling down even to the smallest rural service stores. Any food manufacturer's package will do a far better job if designed with self-service in mind. ${ }^{96}$

The firm also promoted to consumers the idea of self-service through its advertisements for cellophane (Figure 2). Though the primary objective of DuPont was to expand its cellophane market, the company played a critical role in popularizing the idea of self-service merchandising.

In the early 1940s, although neither adequate refrigeration technology nor packaging material was yet available, self-service merchandising began to grow. The labor shortages spawned by World War II helped augment self-service, or semi-self-service, retailing. Almost all butchers at the time were men, and many butchers and meat department retail clerks joined the armed forces. Others turned to higher paying war plant jobs. Many grocers believed that selfservice merchandising would be an effective solution for the labor shortage in the grocery business. ${ }^{97}$ It was not until the postwar years that the majority of meat departments became completely self-service. But many store managers introduced some form of self-service for meat and produce departments during the war. ${ }^{98}$

\footnotetext{
${ }^{95}$ DuPont, Cellophane Division, "Merchandising Trends in Fresh Fruits and Vegetables" (1940); "Self-Service Meats: Progress Report on a Promising New Development" (1945). See also "Super Market Meat Survey' (1940); and "Forward Step in Vegetable Merchandising" (1944), all published by DuPont, Cellophane Division. All in Published Collections Department, HML.

${ }^{96}$ DuPont, "Presentation Book 'Help Yourself,"” Bulletin 32-NN (1938), box 46, DPAD, HML.

${ }^{97}$ Some store operators employed women in their meat department during the war. "Man Power in the Market," Meat Merchandising 18, no. 5 (May 1942): 20; and "The Women Take Over," Meat Merchandising 18, no. 1 (January 1942): 18.

98 "First Self-Service Meats in Arkansas They Made It Work," Meat Merchandising 23, no. 7 (July 1947): 42; and Mayo, The American Grocery Store, 159.
} 


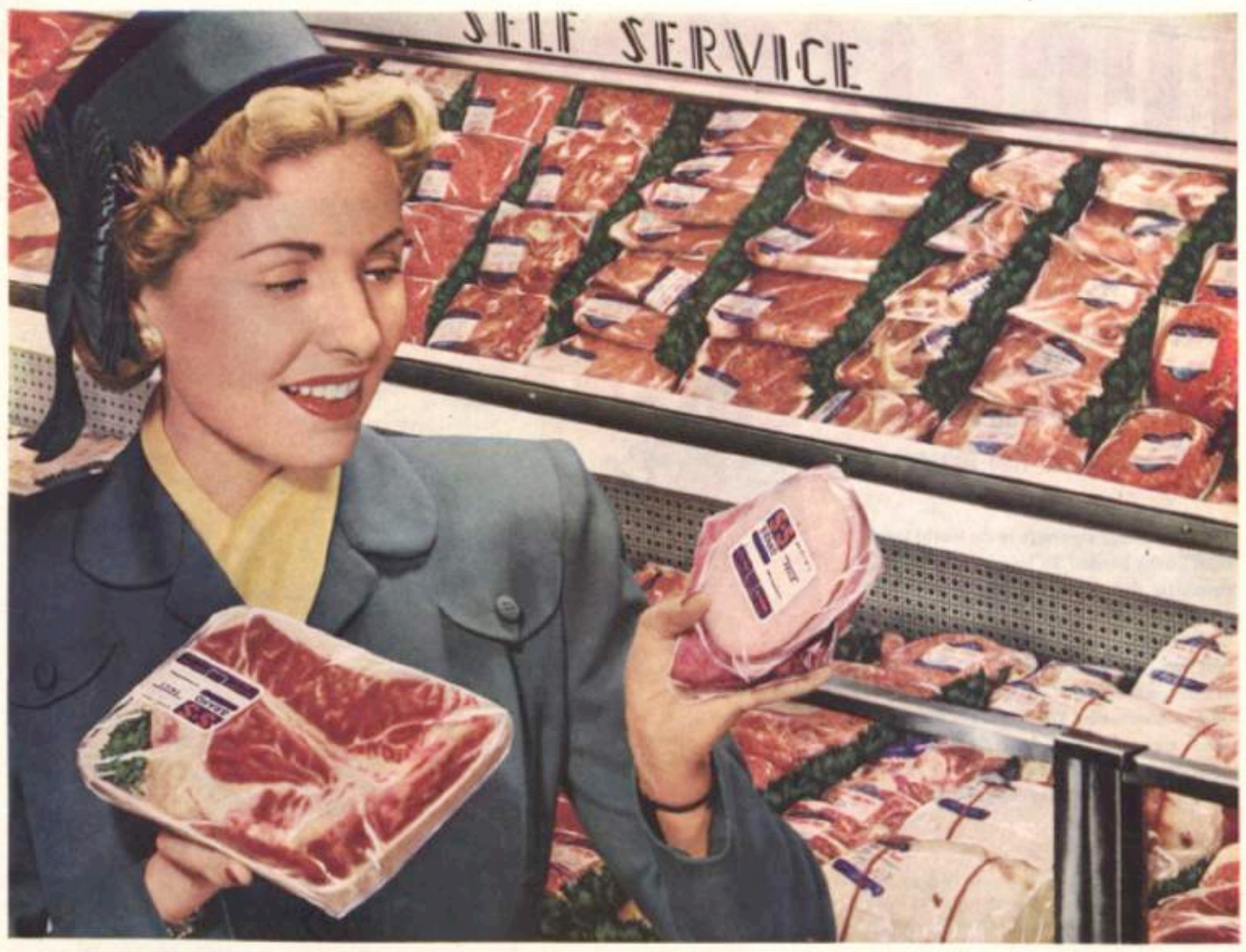

\section{NeW SELF-SERVICE MEATS Make Shopping Quicker, Easier}

You help yourself to the cuts you want -packaged in Du Pont Cellophane-

Hero's the pleasing now way to bay meato-adf-scrvice, just like other foods. Pre-cut, weighed, priced and wrapped in Cellophane right in the store . . . displayed in open, refrigerated cases. You select the cut you want, all trimmed and ready ... you waste no time. Cellophane lets you see exactly what you buy .... keeps the meat fresh and clean.

More and more leading food stores now sell meats this new way. When it comes to your community, we're sure you'll tike it, because it's so convenient and time-saving.
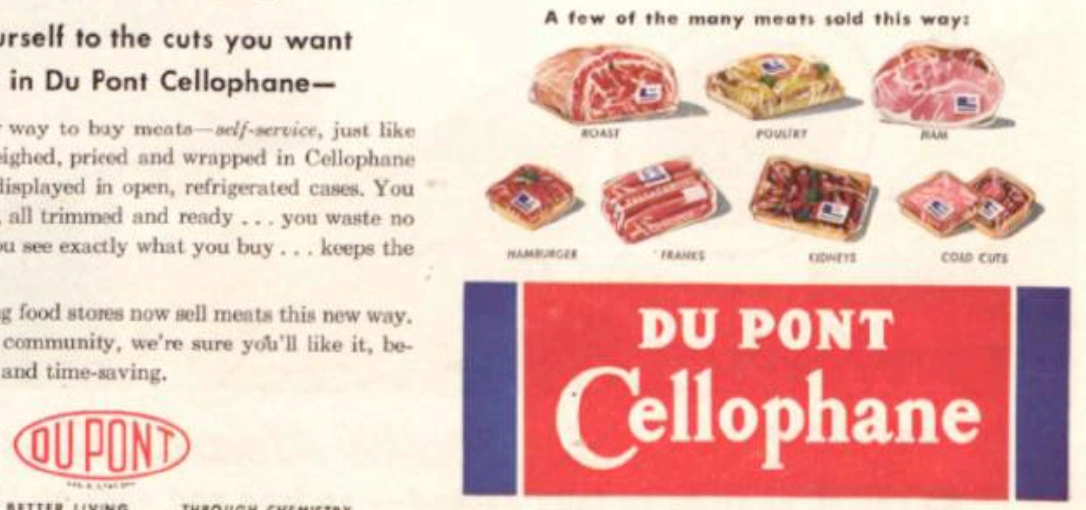

Figure 2: Advertisement for DuPont Cellophane, Saturday Evening Post, 1949, dpads_1803_00320, Series 1, Box 43, Folder 27, DuPont Advertising Department records (Accession 1803), Manuscripts and Archives Department, Hagley Museum and Library, Wilmington, DE. 
The importance of cellophane for self-service operation, especially for meat merchandising, became clear during the war. Cellophane became in short supply as the federal government restricted the use of the film for food packaging and used it instead for war effort since 1942. By 1945, about 75 percent of all DuPont cellophane had been used for war purposes. ${ }^{99}$ The wartime shortage of cellophane worried grocers - particularly those who had not yet adopted self-service merchandising - about the future of self-service operation. Even five years after the war, a grocery trade journal reported in 1950 that the cellophane shortage made many store owners go into semi-self-service rather than complete self-service. They were concerned that they would not be able to sell meat on self-service basis if the cellophane supply completely runs out. ${ }^{100}$ Another trade magazine warned grocers that it would be "a mistake to let the film shortage force you into" a service operation but "it would also be a mistake to go 100 percent self-service now, because of the film shortage." ${ }^{\prime 101}$ To publicize and clarify the cellophane situation, the federal government agency National Production Authority issued a press release in 1952: "cellophane production is now more than adequate to meet present demands and no immediate cellophane shortage can be foreseen."

After World War II, breakthroughs in packaging materials helped expand self-service meat merchandising. In 1946, DuPont finally developed a new transparent film with controlled moisture-proofness and high oxygen transmission rate that provided retailers with an effective packaging material for wrapping self-service meat. ${ }^{103}$ One side of the film was coated with water-resistant nitrocellulose. When the uncoated side was kept in contact with the moist fresh meat, it absorbed the moisture on the meat surface. The outer, coated side prevented the escape

\footnotetext{
99118 F. Supp. 41, no.1, p.134.

100 "Self-Service Meat Forum,” Meat Merchandising 27, no. 6 (June 1951): 92.

101 "Shall I Put in Self-Service Meat Now?" Meat Merchandising 26, no. 11 (November 1950): 26.

102 The Reader Writes, "Plenty of Cellophane," Meat Merchandising 28, no. 9 (September 1952).

${ }^{103}$ Mautz, “A Discussion”; and "Problems in Packaging Meat Products."
} 
of moisture. Both sides of the sheet permitted transmission of a moderate amount of oxygen sufficient to prevent bright red meat from turning to brown. ${ }^{104}$ The new cellophane offered meat department operators other advantages, including ease of handling, clarity, low cost, and adaptability to various sizes of meat cuts. Its strength and resistance to tears also made it possible for shoppers to handle meat wrapped in cellophane without harming the product. In addition, this special fresh meat cellophane offered meat department operators other advantages such as ease of handling, clarity, adaptability to various sizes of meat cuts and relatively low cost. ${ }^{105}$

War-time material shortages and factories converted to war production also curtailed the manufacture of refrigerated cases. But after the war, equipment makers resumed making selfservice meat cases and actively promoted their products. ${ }^{106}$ In a 1946 advertisement, Friedrich Refrigerators Inc. claimed in the trade journal Meat Merchandising: "Your meat looks better and sells better in Friedrich Floating Air Refrigerators." Stressing the importance of visibility and color contrast for meat display, the firm offered a color image of various cuts of meat displayed in its refrigerated case. ${ }^{107}$ In the late 1940s, DuPont developed Freon, which held display cases under $40^{\circ} \mathrm{F}$, as the primary refrigerant for open-topped meat cases. ${ }^{108}$ With open-top refrigerated cases, customers could look down at meat packages lined up neatly in display. They could view the meat from a distance or choose a package that looked good and inspect it up close.

After the war, chain stores like A\&P, rather than independent grocers, led the movement towards the self-service merchandising of fresh meat. Of food stores that had converted selfservice meat departments by 1950, chain stores accounted for 77 percent, and 23 percent were

\footnotetext{
104 "Maximum Salable Life"; Ramsbottom, "Some Aspects of Meat Packaging"; "Problems in Packaging Meat Products"; and Lavers, "Discoloration of Packaged Red Meat," 127.

${ }^{105}$ Lavers, "Discoloration of Packaged Red Meat," 125.

${ }^{106}$ Brand, Modern Supermarket, 32, 34.

${ }^{107}$ Friedrich Refrigerators Inc. Advertisement, Meat Merchandising 22, no. 11 (November 1946): 13.

${ }^{108}$ Deutsch, Building, 188
} 
independents. ${ }^{109}$ By 1953, more than 50 percent of all supermarkets in the United States had offered self-service for packaged fresh meat - a huge increase from 1946 when there were only twenty-eight supermarkets with complete self-service in the meat department. ${ }^{110}$

Innovations in refrigeration and packaging materials also allowed food retailers to prepackage agricultural produce for self-service. Supermarket operators had begun experimenting with the prepackaging of fruits and vegetables during the war years. ${ }^{111}$ Among the first to enter this field was A\&P, which set up test stores in the Columbus, Ohio, area, in 1944 and conducted research on methods for prolonging the shelf-life of perishable products. ${ }^{112}$ Produce departments never became totally dominated by prepackaging or self-service, but by the early 1950s, nearly 45 percent of the produce departments in American supermarkets were operated on a self-service basis. ${ }^{113}$

The popularity of cellophane, as well as other flexible packaging materials reflected a broader shift in food packaging. After World War II, as an increasing number of supermarkets began self-service retailing of perishable items, there was greater demand for consumer size packaging. In addition, cellophane prices decreased and became close to those of waxed paper and glassine. ${ }^{114}$ During this period, demand for cellophane has exceeded supply not only in the United States, but also in Europe and South America. ${ }^{115}$

\footnotetext{
109 "Self-Service Meat Forum," Meat Merchandising 29, no. 2 (February 1953). See also "Self-Service Meat Forum," Meat Merchandising 26, no.10 (October 1950): 78.

${ }^{110}$ Mayo, The American Grocery Store, 159; Sam Teitelman, "Self-Service Meat Retailing in 1950," Journal of Marketing 15, no. 3 (January 1951): 30; and "Self-Service Meat Forum," Meat Merchandising 26, no. 8 (August 1950): 88.

${ }^{111}$ DuPont, "A Forward Step in Vegetable Merchandising"; DuPont, "Merchandising Trends"; and "Produce SelfService Successful," Progressive Grocer 24, no. 8 (August 1945): 140.

${ }^{112}$ Zimmerman, The Super Market, 147.

${ }^{113}$ Ibid.

114 118 F. Supp. 41, no.1, p.135.

${ }^{115}$ Ibid., p.134.
} 
By 1950, grocers expanded the use of cellophane to various food products, ranging from baked goods, fresh and cured meats, candy, crackers and biscuits, frozen foods, fruits and vegetables, to potato chips and other snacks. Food packaging accounted for about 80 percent of DuPont's cellophane sales in $1949 .{ }^{116}$ In the mid-twentieth century, among food products, cellophane was used most often for agricultural produce and meat. While cellophane was used only 7 percent of packages for baked products, the film accounted for 47 percent for agricultural produced and 35 percent for meat. Approximately 45 percent of cake and baked sweet goods packaged by wholesale bakers was wrapped in DuPont cellophane. The film also furnished 47 percent of wrappings for fresh produce, between 25 and 35 percent for candy, 25 to 30 percent for crackers and biscuits, 20 to 30 percent for frozen foods, and 20 to 30 percent for potato chips and other snacks. $^{117}$

Self-service operation provided various advantages both to grocers and consumers. The one advantage was that women did not have to wait for service. Self-service also allowed shoppers to buy exactly the quantity and kinds of meat they wanted. They could look down at meat packages lined up neatly in a refrigerated display case with an open top. They could also touch the meat gently through the cellophane wrapping. Moreover, small-income customers were no longer "embarrassed" by ordering small quantities. ${ }^{118}$ One article featured in the trade journal Meat Merchandising claimed: "as much as women may like self-service in the super-market, it probably will never replace full service."119 Many other trade journals and grocery manuals also

\footnotetext{
${ }^{116}$ The largest non-food use of cellophane was the overwrapping of cigarette packages (about $11 \%$ of DuPont's total sales of cellophane). A small amount was sold for wrapping of textiles and paper products. $118 \mathrm{~F}$. Supp. 41, no.1, p.111.

${ }_{117} 118$ F. Supp. 41, no.1, p.110, 113-15; 351 U.S. 377, p.23.

118 “100\% Self-Serve Meats Increase Sales 20\%," Meat Merchandising 18, no. 4 (April 1942).

119 "Self-Service for Meat Uncorks."
} 
claimed that the majority of female shoppers preferred self-service to conventional counterservice. $^{120}$

For grocery operators, self-service provided the opportunity for better control over the store operation, enabled greater standardization of cutting, trimming, and packaging of meats, and permitted the display of a wide variety of products. ${ }^{121}$ One market study conducted by Iowa State College Study in the early 1950s concluded that the average costs of counter-service and of self-service operations were not sufficiently different, but most stores which had switched to self-service saw sales increase. Their cost was lower because of the larger volume of sales - not because self-service in itself was a lower-cost method of retailing, the study reported. ${ }^{122}$

Also in the produce section, packaged fruits and vegetables were generally more advantageous to grocers than selling produce in bulk: less waste, increased profit, and faster service. ${ }^{123}$ Careless handling by consumers and store clerks often damaged fruits and vegetables. Customers for instance tended to toss lettuce around the display case, and the leaves became loose, fell off, and discolored. When a head of lettuce was in a package, it could withstand handling by consumers and retailers. ${ }^{124}$ At a supermarket in Belleville, Illinois, losses of lettuce fell to under 2 percent as compared with 11 to 12 percent losses before the store started prepackaging every head individually. ${ }^{125}$

\footnotetext{
${ }^{120}$ See for example, Eisner, "What We Have Learned"; "Food Shoppers and Food Selling"; and "Fruits and Vegetables Offer Best Chance."

121 "Self-Service Meats," Meat Merchandising.

122 "Meat Retailing - Service or Self-Service?" Meat Merchandising 29, no. 10 (October 1953): 45.

123 "How Self-Service Experts Sell Fresh Fruits \& Vegetables," Progressive Grocer 24, no. 8 (August 1945): 66; George E. Kline, "How Super Valu Stores Package Produce for Better Sales, Margins, Profits," Progressive Grocer 33, no. 8 (August 1954): 56; and "Produce Self-Service Successful," Progressive Grocer 24, no. 8 (August 1945): 140 .

124 "How to Pre-Package Lettuce at Retail Level," Meat Merchandising 29, no. 1 (January 1953): 29

125 "Pre-Packaging Has Boosted My Gross Profit on Produce by 7 Percent," Meat Merchandising 28, no. 10 (October 1952): 37-38.
} 
A drop in spoilage losses, as well as better appearance, meant better profits and better sales. Prepackaged vegetables generally outsold those sold in bulk, even when bulk produce was less expensive. ${ }^{126}$ In one supermarket in Wichita Falls, Texas, produce sales rose from 12 percent of total store sales to 20 percent within a few months after switching to self-service retailing of prepackaged produce in $1946 .{ }^{127}$ According to a 1954 survey, a store in Minnesota increased the produce department's share of total store sales an average of 2.5 percent after converting to complete self-service of packaged produce. ${ }^{128}$

Convenience for consumers was another advantage of packaged self-serve produce. ${ }^{129}$ Packaged fruits and vegetables were easier to carry and store. There was no need for customers to wait for a clerk to weigh and price the merchandise. They had ample time to make selections and comparisons from a large variety of produce attractively displayed in open refrigerated cases. ${ }^{130}$ In addition, it was no longer necessary to shop for fruits and vegetables early in the day, soon after they arrived at the store, because packaging and refrigeration in the store guaranteed that everything stayed "just as fresh, crisp, and healthful" later in the day as it was in the morning. ${ }^{131}$ Produce also kept longer in the home, for when only a portion of the whole vegetable or fruit was used, consumers could store the remaining part in the package and put it back in the refrigerator. Consumers generally preferred prepackaged self-serve produce to bulk

\footnotetext{
${ }^{126}$ No title, Progressive Grocer 27, no. 4 (April 1948): 124; and "Tests in Sixty Stores Prove Prepackaging Lifts Produce Sales," Progressive Grocer 33, no. 7 (July 1954): 40.

127 John D. Lucas, "Why We're Strong for Prepackaged Produce in Open Refrigerated Cases," Progressive Grocer 26, no. 1 (January 1947): 72.

${ }^{128}$ Kline, "How Super Valu Stores," 52.

${ }^{129}$ Eisner, "What We Have Learned."

${ }^{130}$ No title, Progressive Grocer, 124; and Lucas, "Why We're Strong," 72.

${ }^{131}$ John R. Mitchell, "I Slashed Spoilage and Boosted Produce Sales by Prepackaging + Refrigeration," Progressive Grocer 26, no. 4 (April 1947): 193.
} 
retailing. One market study reported that nearly 90 percent of women interviewed preferred to buy tomatoes in transparent wrapping. ${ }^{132}$

This new retailing system transformed the relationships between customers and store clerks. The bright produce and meat display provided customers with visual information about the freshness of the product while eliminating clerk-customer interactions. ${ }^{133}$ In a meat department, butchers and "wrapping girls" who weighed and wrapped meat usually worked in a back room. ${ }^{134}$ Produce section clerks also became involved mainly in prepackaging produce in a specially-designed room commonly at the rear of the store. ${ }^{135}$ Some retailers considered this virtual disappearance of personal contact disadvantage, and sought to keep some relationships between customers and store clerks by using hostesses. ${ }^{136}$ Yet as self service gradually became the norm, consumers increasingly relied on their eyes in selecting foods in modern supermarkets where bright foods were presented while human labor was disguised.

\section{Problems of Better Visibility}

Cellophane's transparency, which was supposed to help create eye-appealing display in food stores, turned out to be a source of merchandising problems. According to a 1947 market study on cellophane-wrapped bread, conducted by Ernest Dichter, cellophane's transparency robbed people of the "gratifications of curiosity and surprise." ${ }^{\prime 37}$ One female respondent stated that "the fact that you [could] see the bread [was] not so important." She continued, "Perhaps I

\footnotetext{
${ }^{132}$ DuPont, "You Can Sell More Tomatoes: A Consumer and Retail Store Survey on the Use of a 'Cellophane' Transparent Wrap" (1934), box 45, DPAD, HML.

${ }^{133}$ For the historical transformation of the relationships between grocery employees and consumers, see Deutsch, Building.

134 "They Pre-Package All Perishables," Meat Merchandising 23, no. 3 (March 1947): 42; "Operating Costs," Meat Merchandising 24, no. 6 (June 1948): 70

135 "Big Boom in Self-Service Meats," Meat Merchandising 25, no. 6 (June 1949): 39; and Mayo, The American Grocery Store, 177-78.

136 "Self-Service Meats," Meat Merchandising.

${ }^{137}$ Ernest Dichter, "An Exploratory Psychological Study."
} 
don't want to see what I'm getting to get. I like to be surprised, like a gift."138 Dichter contended that for some products "the curiosity to see what [consumers] were buying was outbalanced by the consumer's desire not to see the product, at least, not before it was unpacked."139 Even in the case of everyday foods, some consumers seemed to enjoy the thrill and curiosity that transparency failed to offer.

Other interviewees expressed their "shame for the bread's "nakedness"” and the "unnecessary exposure" under a transparent film. ${ }^{140}$ A 40 year-old woman noted: "Whole wheat or rye breads and pumpernickel should be wrapped in cellophane because they are tanned and can afford to be naked. I wouldn't like white bread in a transparent wrapper."141 Another respondent similarly compared the color of bread to the color of skin: "dark rye and pumpernickel in cellophane wrappers to me looks like attractive, sun-tanned skin under lace or a veil." "142 These consumers' response to cellophane-wrapped white bread indicated the emergence of new aesthetic criterion for bodies, both human and non-human. Until the first decades of the twentieth century, sun-tanned skin had symbolized working classes who labored outside under the sun. By the 1930s, however, Americans began associating sun-tanning as an aspirational, aesthetic feature. $^{143}$

Nonetheless, consumers' demand for white bread at the time far exceeded demand for whole wheat or any other brown bread. ${ }^{144}$ Consumers' perception about whiteness of bread and skin color hence made transparency problematic. Bread makers also showed uneasy feelings

\footnotetext{
${ }^{138}$ Ibid.

${ }^{139}$ Ibid. [emphasis in original].

${ }^{140}$ Ibid.

${ }^{141}$ Ibid.

142 Ibid.

${ }^{143}$ Geoffrey Jones, Beauty Imagined: A History of the Global Beauty Industry (New York: Oxford University, 2010); and Kerry Segrave, Suntanning in 20th Century America (Jefferson, NC: McFarland, 2005).

${ }^{144}$ Sigfried Giedion, Mechanization Takes Command: A Contribution to Anonymous History (New York: Oxford University Press, 1948), 198-99.
} 
towards cellophane-wrapped white bread and refrained from using transparent wrapping for their breads. ${ }^{145}$ In fact, about 96 percent of packaged white bread produced in the United States in 1949 was wrapped in waxed paper or glassine, and about 6 percent in cellophane. Forty-eight percent of non-white specialty breads, such as raisin bread, were wrapped in DuPont cellophane, and the remainder in other cellophane or other materials. ${ }^{146}$ As a solution for wrapping white bread with cellophane, Dichter recommended to his customer to make white bread look less "naked" by making cellophane in darker shades or adding "stripes of some very dark color" to the wrapper. ${ }^{147}$ Cellophane could keep bread clean and fresh, helping bakers to distribute massproduced bread. However, the transparent film exposed to consumers a "naked body" something they did not want to see.

Later in the 1960 s, cellophane-wrapped white bread began to pose another problem to bakers and grocers. During the early- to mid-twentieth century, the public image of white bread and of cellophane (or plastic more broadly) changed dramatically in the United States. In the first decades of the twentieth century, both white bread and plastic symbolized scientific progress and modernity. However, consumers began associating white bread with bland, homogeneous life styles in the 1960 s, and with "white trash" in the 1980s. ${ }^{148}$ Plastic also came to signify the culture of mass consumption, artificiality, and waste in the late twentieth century. ${ }^{149}$ White bread thus became an apt exemplar of so-called "plastic foods.","150

\footnotetext{
${ }^{145}$ Dichter, “An Exploratory Psychological Study”; and DuPont, “Bread Engineers' Conference,” Bulletin 32-PP (1939), DPAD, HML.

${ }_{146} 118$ F. Supp. 41, no.1, p.114-15.

147 Dichter, "An Exploratory Psychological Study."

${ }^{148}$ Warren Belasco, Appetite for Change: How the Counterculture Took on the Food Industry (Ithaca: Cornell University Press, 1989), 48-50; and Aaron Bobrow-Strain, White Bread: A Social History of the Store-Bought Loaf (Boston: Beacon Press, 2012), 149-50.

${ }^{149}$ Meikle, American Plastic.

${ }^{150}$ Belasco, Appetite for Change, 37-42; and Tom Fisher, "Plastics in Everyday Life: Polymorphous (In)authenticity," in Plastics: Looking at the Future and Learning from the Past: Papers from the Conference Held
} 
Transparency became an issue also for meat packers because cellophane facilitated the discoloration of foods, particularly cured meat products. Due to the increasing use of transparent packaging in mid-twentieth-century supermarkets, meat products were always exposed to direct light, which accelerated discoloration. The degree of meat discoloration depended on the intensity of the light and the length of time the meat was exposed. Processed meats discolored faster than fresh meats. Intense light discolored cured meats by stimulating oxidation of the products within one hour after slicing. Thus to prevent fading of meat colors, exposure to strong lighting or to oxygen needed to be avoided completely.

Especially after the development of fluorescent lights, discoloration became a critical problem for many grocery operators. Until the late 1930s, many supermarkets had installed ordinary over-size lamps, usually incandescent tungsten bulbs, which generated heat and accelerated the darkening of meat and wilting of fresh produce. Fluorescent lights were less likely to discolor meat products than incandescent bulbs. Yet fluorescent lights still deteriorated the color of both fresh and cured meats when lighting was strong. ${ }^{151}$ The store lighting in the new or remodeled market was generally much brighter than earlier stores due to new design and new types of light bulbs. Many retailers used stronger light for better visibility in the entire store and display cases, increasing the amount of light that reached meats. ${ }^{152}$ The average open display case of the early 1950s was equipped with sixty foot-candles of light - enough to discolor bacon in half a day. After two days this brightness made the product "completely unsaleable."153 If light

at the Victoria and Albert Museum, London, 23-25 May 2007, eds. Brenda Keneghan and Louise Egan (London: Archetype, 2008): 145-52.

151 "Store Lighting and Meat Sales," Meat Merchandising 29, no. 4 (April 1953): 62-63; and "Self-Service Meat Forum," Meat Merchandising 27, no. 8 (August 1951): 64.

152 "How Can I prevent Discoloration," Meat Merchandising 27, no. 7 (July 1951): 44; and "What Prevents Discoloration," Meat Merchandising 28, no. 6 (June 1952): 40-41.

153 "How Can I prevent Discoloration," 44. 
was less intense, discoloration could be retarded for half a day; but if the product was not selling rapidly, light needed to be blocked entirely. ${ }^{154}$

During the 1930s and 1940s, lighting manufacturers, particularly the General Electric Company, the Westinghouse Electric and Manufacturing Company, and Sylvania Electric Products, devoted considerable resources to develop better lighting equipment for grocery as well as other businesses. In the late 1940s, the trade journal Meat Merchandising advised retailers that the only fluorescent tube that they should use for meat was the "soft white" color, which had a pinkish and slight yellowish cast. Some of these soft white tubes were developed particularly for meat lighting, to slow the color changes of meat and make the product look more attractive. ${ }^{155}$ General Electric recommended its "deluxe cool white" light for meat display. Like soft white, it contained a pinkish shade and emphasized warm colors, including pink and red colors of meat products. ${ }^{156}$

For meat retailers, "discoloration" meant not merely the physical change of meat color but a loss of sales appeal as well as the deterioration of visual environment in the entire store. "Ten thousand retailers with the same headache! The seriousness of this [discoloration] problem must not be underestimated," the trade journal Meat Merchandising declared in 1950:

The usual pleasant aura surrounding food shopping is lost, and it is difficult to measure total store sales lost by lack of appeal of one discolored slice of meat. Ironically, fading can by no means be used as an indication of quality in luncheon meats. A slice of meat may be rancid, overage and spoiled, and still have an appetizing appearance. On the other hand, fresh sausage which has been exposed to light for several hours, although still tasty may frighten sausage eaters away by its gray appearance. ${ }^{157}$

Stressing the importance of eye appeal, the author indicated that the sense of sight was more important than taste in selling and purchasing meat. Especially in self-service stores, where

\footnotetext{
${ }^{154}$ Ibid.; and "What Prevents Discoloration," 40-41.

155 “Discolored Meat?" Meat Merchandising 24, no. 8 (August 1948): 43.

156 "Store Lighting and Meat Sales," 66.

157 "Fading in Processed Meats," Meat Merchandising 26, no. 10 (October 1950): 41.
} 
consumers could not taste the product and had fewer opportunities to ask store clerks about product quality than at butcher shops, they could in fact be "frighten[ed]" by the "gray appearance" of meat without knowing whether the product was deteriorated.

The improvement of packages was one way to prevent the discoloration of cured meats. In the 1950s, several large meat packers introduced vacuum packaging to prevent oxidation. But it was impractical in a retail operation without sufficient equipment. ${ }^{158}$ Retailers tried to solve the discoloration problem by placing a piece of waxed paper on one side of each package. Wrapped packages were displayed in a self-service case, waxed paper side up. The paper shut out the light from inside the package while the other side of the package allowed consumers to see the product. The waxed paper also shielded cured meats from the heat of the sealing iron, used for closing the wrapper and attaching a label. Yet customers needed to pick up a package and turn it over to see the product. ${ }^{159}$ Retailers also experimented with a so-called "stop light label" (also known as the coverall label, full face label, and picture pack label). It covered the whole face of the package, blocking out all light on the exposed side. While the package did not show the actual product, a full color illustration of a product helped consumers know which item was in the package. ${ }^{160}$ Still, the most practical means of maintaining maximum sales appeal in the display and for minimizing discoloration was to supervise the display frequently and to rotate packages, although this operation increased labor costs.

Meat packers and retailers also manipulated physiological and chemical constituents of meat by using food additives, rather than adjusting external conditions (such as bright lights), to give the products a particular color that consumers considered "fresh." Since the nineteenth

\footnotetext{
${ }^{158}$ Horowitz, Putting Meat, 66-67; and “Stop Discoloration,” Meat Merchandising 25, no. 10 (October 1949 ): 72. 159 "Stop Discoloration," 72.

160 "Here's How to Know What Prevents Discoloration,” Meat Merchandising 28, no. 6 (June 1952): 40-41; “How Can I prevent Discoloration," 44; and "Self-Service Meat Forum," Meat Merchandising 27, no. 4 (April 1951 ): 77.
} 
century, meat packers had been adding synthetic dyes to sausages and other meat products to give them a "fresh" and "natural" red shade of meat. Meat packers and processors also used sweeteners to maintain the red color of cured meats and add flavor to the finished products. ${ }^{161}$ Later in the mid-twentieth century, chemical companies introduced various additives, such as chemical preservatives, for preventing the discoloration of cured meats. ${ }^{162}$ In the 1940 s, chemical firms, including Pfizer, Inc. and Calgon, Inc., began supplying antioxidant additives, particularly a substance called ascorbic acid, which would keep bright color of cured as well as fresh meats. ${ }^{163}$ "In hams color makes sales!" Calgon proclaimed in an advertisement for ascorbic acid product in $1956 .{ }^{164}$ Sterwin Chemicals Inc., which also manufactured ascorbic acid additives, declared that "since customers usually 'buy by eye' these products have a plus that means extra salability. ${ }^{\not 65}$ Similarly, in promoting its antioxidant additives, Merck \& Company touted the "eye appeal" that its products provided and asserted that "consumer appeal in meat [was] largely a matter of product color." ${ }^{166}$ The addition of dyes, sweeteners, and preservatives made meat products "chemically fresh" and provided retailers with more stable and reliable ways of manipulating the freshness of foods than refrigeration and packaging.

\section{The Rise of New Packaging Materials}

In the early 1950s, DuPont's share of the cellophane market began to decline. In 1951, the chemical company Olin Industries, Inc., entered the cellophane market. Olin's subsidiary, Ecusta Paper Corporation, was engaged in the production of cellophane in Pisgah Forest, North

\footnotetext{
${ }^{161}$ Y. H. Hui, ed., Handbook of Meat and Meat Processing (Boca Raton, FL: CRC Press, 2012), 488-89, 532.

162 "Meat Stabilizer," Meat Merchandising 25, no. 9 (September 1949): 36.

${ }^{163}$ Kenneth J. Carpenter, The History of Scurvy and Vitamin C (New York: Cambridge University Press, 1986), 20910; Hui, Handbook of Meat, 537; and M. D. Ranken, "The Use of Ascorbic Acid in Meat Processing," in Vitamin C (Ascorbic Acid), ed. J. N. Counsell and D. H. Corning (New York: Applied Science, 1981).

${ }_{164}$ Calgon, Inc., Advertisement, National Provisioner 135, no. 2 (July 13, 1956): 28.

165 Sterwin Chemicals Inc., Advertisement, National Provisioner 134, no. 8 (August 1956): 43.

${ }^{166}$ Merck \& Co. Inc., Advertisement, Meat Magazine (June 1958).
} 
Carolina ${ }^{167}$ By that time, the 20 percent limiting clause, contracted between DuPont and Sylvania, had been dropped. Although the amount of cellophane produced by DuPont was larger than the other two manufacturers, its share dropped from 80 percent of total domestic cellophane production at its peak to 68 percent by the early 1950 s. ${ }^{168}$

By 1960, grocery operators also began to question the effectiveness of cellophane as a package material for fresh meats. ${ }^{169}$ Cellophane, for example, was difficult to automate. In 1966, 775 percent of self-serve meats were still wrapped by hand at the meat department. ${ }^{170}$ By the mid-1960s, cellophane was almost entirely replaced by polyvinyl chlorides (PVC) films. Like cellophane, PVC films offered the similar protection against moisture loss and oxygen permeability, which allowed the fresh meat to "bloom." But PVC was less expensive, far clearer, less likely to wrinkle, and better in protecting the meat than cellophane. ${ }^{171}$ DuPont cellophane, once a key driver of expanding and popularizing self-service operation, became less suitable for the fast-changing market that required further mechanization, efficiency, and consistency.

\section{Conclusion}

This working paper has shown how DuPont's marketing rhetoric and innovations in cellophane helped expand self-service food retailing in the United States. The technological development of packaging and store equipment between the 1920s and 1950s enabled grocers to establish a new retailing system. This both transformed the way grocers sold and presented foods to customers and created a new visual environment in the store. Transparent packages,

\footnotetext{
167118 F. Supp. 41, no.1, p.26.

${ }^{168}$ Ibid., no.2, p.67. In May1952, DuPont's annual productive capacity was 218,000,000 lbs., Sylvania's was 72,000,000 lbs., and Olin's was 34,000,000 lbs.

${ }^{169}$ Mautz, "A Discussion."

${ }^{170}$ Horowitz, Putting Meat, 142.

${ }^{171}$ Ibid., 143-44; Jenkins and Harrington, Packaging Foods with Plastics, 111; and Mautz, "A Discussion."
} 
refrigerated display cases, and lighting equipment enabled grocers to create bright, clean, and orderly displays of produce and meat, providing consumers a sense of freshness. As this working paper has demonstrated, this new visuality rested on retailers' and package manufacturers' desire for commercial expansion, gendered understanding of food consumption, and technological manipulation.

The expansion of self-service retailing and of the use of cellophane dramatically altered how consumers understood food quality. The visual perception of freshness became increasingly separated from the temporal definition. Modern store equipment and packaging materials provided consumers a new way of understanding product quality, as well as a new buying experience. Customers looking at shining tomatoes and bright red meat made assumptions about their quality based largely on how they looked, rather than how much time had passed after fruits and vegetables were harvested and meat was packaged. Freshness was no longer a natural state of foods but a marker of marketability that producers and retailers carefully controlled in a sanitized, standardized environment.

In a self-service store, where the work of grocers became increasingly invisible to customers, the natural beauty and abundance that fresh foods embodied became a product of constant control and close supervision by store clerks. Transparent packages provided consumers with better visibility while allowing retailers to control and maintain a fresh, bright look of perishable foods. Refrigerated display cases also enabled grocers to prolong the freshness of produce and meat. Bright meat bloom, shining red tomatoes, and brilliant green spinach, sealed in transparent film, represented “industrial freshness.” As Bett Hooper’s book indicated, cellophane packages were expected to protect the "virginity" of the content and presented it as pure and untouched. But, in fact, keeping the virginity involved tremendous human manipulation. 